\title{
OS JUIZADOS ESPECIAIS FEDERAIS, A LEI No 13.994/20 E O PROCESSO JUDICIAL PREVIDENCIÁRIO: AUDIÊNCIAS NÃO PRESENCIAIS (VIRTUAIS) DE CONCILIAÇÃ̃O ${ }^{1}$
}

THE SMALL CLAIM COURTS, THE BRAZILLIAN LAW 13.994/20 AND THE SOCIAL SECURITY DUE PROCESS: AND THE NON-PRESENTIAL (VIRTUALS) CONCILIATION HEARING

Marco Aurélio Serau Junior Doutor e Mestre em Direitos Humanos pela USP Universidade de São Paulo. Diretor Científico do IEPREV Instituto de Estudos Previdenciários. Professor da UFPR Universidade Federal do Paraná. Curitiba/PR. E-mail: maseraujunior@hotmail.com.

Alberto Luiz Hanemann Bastos Bastos Mestrando em Direitos Humanos e Democracia pela Universidade Federal do Paraná - UFPR. Bacharel em Direito pela mesma instituição. Pós-graduando em Processo Civil pelo Instituto de Direito Romeu Felipe Bacellar - IDRFB. Advogado. Canoinhas/SC. E-mail: alberto.bastos.1997@gmail.com.

RESUMO: O presente artigo discute o alcance da Lei 13.994/2020, que permitiu a realização de audiências de conciliação não presenciais no âmbito dos Juizados Especiais Cíveis e Juizados Especiais Federais. Considerando que inúmeras demandas sobre benefícios previdenciários são instauradas em tais órgãos jurisdicionais, pretendeu-se avaliar em que medida as conciliações virtuais se mostram (in)adequadas a essa realidade específica dos litígios previdenciários. Concluiu-se que o objetivo de aumento de eficiência através do emprego da tecnologia não pode descurar das características das ações previdenciárias, em

\footnotetext{
${ }^{1}$ Artigo recebido em 15/04/2021 e aprovado em 22/08/2021.
} 
especial a usual hipossuficiência informacional dos litigantes e o conhecido problema da exclusão digital.

PALAVRAS-CHAVE: Direito. Processo. Juizados Especiais. Tecnologia. Audiência.

\begin{abstract}
This article discuss the range of application of the Brazillian Law 13.994/2020, which permitted the celebration of non-presential (virtual) conciliation hearing in the small claim courts sphere. Considerind the high number of sues involving the dispute over social security benefits in these courts, it was analysed whether virtual conciliation are (un)suitable to the specific context of social security litigation. It was concluded that the increase of the efficiency through the use of technology cannot neglect the characteristics of social security action, like the usual informacional vulnerability of the plaintiffs and the wellknown problem of digital exclusion.
\end{abstract}

KEYWORDS: Law. Civil procedure law. Small claims courts. Technology. Conciliation hearing.

\title{
1. INTRODUÇÃO
}

Este artigo pretende discutir o alcance da Lei 13.994/2020 no âmbito dos Juizados Especiais Federais.

Esse diploma legal, editado no cenário de medidas normativas que visam adequar o ordenamento jurídico à situação de isolamento social decorrente do enfrentamento da disseminação do novo coronavírus (COVID-19), permitiu a realização de audiências de conciliação não presenciais (virtuais) no âmbito dos Juizados Especiais Cíveis, alterando os artigos 22 e 23 da Lei 9.099/95.

Porém, conforme disposição do art. $1^{\circ}$, da Lei 10.259/2001, o procedimento dos Juizados Especiais Cíveis é aproveitado no bojo dos Juizados Especiais Federais, no que não conflitar com as regras específicas adotadas nessa competência jurisdicional. Por isso, tal dispositivo também se aplica à realidade dos Juizados Especiais Federais. 
Ocorre que uma das modalidades mais comuns de demandas que tramitam na esfera dos Juizados Especiais Federais consiste nos litígios previdenciários, por meio dos quais os segurados da Previdência Social almejam algum dos benefícios fornecidos pelo poder público para fazer frente às contingências resguardadas pela lei, a exemplo da invalidez, da idade avançada e da morte de um dos entes mantenedores do núcleo familiar.

Por envolver interesses econômicos ligados ao INSS, autarquia vinculada à União, a competência para o julgamento desse tipo de demanda é destinada à Justiça Federal, nos termos do art. 109, inciso I, da Constituição. Não obstante, é bastante comum que as demandas de cariz previdenciário sejam instauradas nos Juizados Especiais Federais, pois, dadas as inúmeras atribulações da realidade econômica pátria, a maioria dos segurados da Previdência Social recebem benefícios em valor próximo ao salário-mínimo, o que resulta geralmente em ações cujo valor da causa é valor inferior a 60 (sessenta) salários-mínimos, mesmo com a consideração das parcelas atrasadas.

Assim, não há dúvidas de que as novas disposições carreadas pela Lei 13.994/2020 tem potencial para desencadear repercussões bastante significativas nas demandas previdenciárias instauradas perante os Juizados Especiais Federais.

É preciso ressalvar, porém, que os litígios previdenciários são marcados por uma série de particularidades que os diferenciam do "processo civil comum", a exemplo da assimetria existente entre o indivíduo que pleiteia o benefício previdenciário e o INSS, bem como a presumível hipossuficiência do polo ativo da demanda. Em razão disso, é preciso que as inovações premeditadas pela Lei 13.994/20 sejam analisadas de maneira crítica, de modo a verificar se elas garantem a tutela adequada do direito material disputado na realidade específica dos litígios previdenciários, sobretudo num contexto marcado por um imenso contingente populacional que não possui acesso aos serviços de internet - situação conhecida na doutrina por exclusão digital ou "vulnerabilidade cibernética".2

Com fulcro nessas premissas, este artigo, inicialmente, retoma a discussão que motivou a criação dos Juizados Especiais Federais, qual seja, a perspectiva de facilitação do acesso à justiça em relação às pequenas causas que tenham como mote a concessão ou

\footnotetext{
${ }^{2}$ TARTUCE, Fernanda; BRANDÃO, Débora. Mediação e conciliação online, vulnerabilidade cibernética e destaques do ato normativo $\mathrm{n}^{\circ}$ 1/2020 do NUPEMEC/SP. Cadernos Jurídicos, São Paulo, ano 21, n. 55, jul./set., 2020, p. 154-155.
} 
revisão de benefícios previdenciários, analisando criticamente o atual estágio dessa modalidade de jurisdição.

Na sequência, expõe-se as alterações procedimentais trazidas pela Lei 13.994/2020, em particular o modo pelo qual pode ocorrer a audiência não presencial de conciliação e seus efeitos jurídicos, bem como seu enquadramento nas regras processuais gerais e a necessidade de regulamentação do tema pelos Tribunais e Corregedorias.

Ao final, discute-se criticamente a aplicação dessa inovação ao cenário específico das ações previdenciárias, que é pautado por uma relevante assimetria processual entre as partes em litígio.

O objetivo é demonstrar que a inovação da Lei 13.944/2020 é essencialmente positiva, mas deve ser considerada com certas ressalvas e cuidados quando aplicada nos Juizados Especiais Federais, diante das características inerentes a esse âmbito jurisdicional, sobretudo as vulnerabilidades processuais que configuram o polo ativo das ações previdenciárias.

A metodologia utilizada na elaboração deste artigo é, eminentemente, analíticobibliográfica, não tendo ocorrido pesquisa empírica - em que pese não ser possível descartar a prévia experiencia profissional de ambos os autores do texto nesta área do Direito.

\section{OS JUIZADOS ESPECIAIS NA PERSPECTIVA DO ACESSO À JUSTIÇA}

Desde a consolidação do entendimento de que o processo civil detém funções e escopos de atuação que extrapolam a mera conformação procedimental das contendas travadas perante a autoridade judiciária ${ }^{3}$ é lícito assumir que o tema do "acesso à justiça" jamais deixou de integrar a pauta do direito processual.

É certo que o acesso à justiça não se esgota na mera prerrogativa de apresentação da petição inicial; muito mais do que isso, é necessário que o legislador erija procedimentos adequados à natureza do direito material discutido em juízo e, principalmente, às

\footnotetext{
${ }^{3}$ Neste particular, remete-se às clássicas lições doutrinárias do direito processual civil. A título ilustrativo, vale conferir: MOREIRA, José Carlos Barbosa. A função social do processo civil moderno e o papel do juiz e das partes na direção e na instrução do processo. Revista de Processo, São Paulo, v. 37, 1985, p. 140-150. De igual modo: DINAMARCO, Cândido Rangel. A instrumentalidade do processo. 14. ed. São Paulo: Malheiros, 2009, p. 178-184.
} 
particularidades financeiras, sociais e materiais dos litigantes que costumam se revelar num determinado contexto judicial. ${ }^{4}$.

Conforme leciona Rodolfo de Camargo Mancuso, para que o direito fundamental de acesso à justiça torne-se uma realidade viva no cotidiano forense, compete "ao legislador processual excogitar e positivar os meios adequados para assegurar a efetividade prática do quanto estabelecido nos comandos judiciais de mérito". 5

É justamente com base neste ideal de adequação procedimental que o art. 98, inciso I, da Constituição Federal, e a Lei 9.099/95, instituíram os Juizados Especiais, os quais, norteados pelos princípios da gratuidade, celeridade, informalidade, economia processual e primazia pela solução consensual dos conflitos, prestam-se ao manejo de litígios de menor complexidade.

Trata-se de movimento normativo associado à remoção das barreiras econômicas, sociais e culturais que impedem o acesso ao Poder Judiciário, principalmente dos indivíduos desprovidos de recursos financeiros para arcar com o pagamento das custas processuais exigidas pelo procedimento comum.

Em virtude do acesso gratuito e da ausência das formalidades usualmente presenciadas no ambiente forense, os Juizados Especiais permitem que a jurisdição alcance indivíduos que não teriam os seus direitos concretizados em meio aos entraves do rito comum, sobretudo num país em que parcela significativa da população sequer tem acesso às garantias básicas de uma vida digna - tais como moradia adequada, saneamento básico, saúde e educação de qualidade -, tampouco de exercerem plenamente seus direitos civis e políticos. ${ }^{6}$

\footnotetext{
${ }^{4}$ Ao descreverem o conjunto de valores que animaram a criação dos Juizados Especiais Federais, Sérgio Cruz Arenhart, Luiz Guilherme Marinoni e Daniel Mitidiero acentuam que tais instâncias foram inicialmente cogitadas para densificar a cláusula do acesso à justiça e do direito à assistência judiciária gratuita nos pedidos afeitos à competência da Justiça Federal, a exemplo das demandas de cariz previdenciário. Para maiores informações: ARENHART, Sérgio Cruz; MARINONI, Luiz Guilherme; MITIDIERO, Daniel. Novo curso de processo civil: tutela dos direitos mediante procedimentos diferenciados. 3. ed. São Paulo: Revista dos Tribunais, 2017, v. 3, p. 45.

${ }^{5}$ MANCUSO, Rodolfo de Camargo. Acesso à justiça: condicionantes legítimas e ilegítimas. 3. ed. Salvador: Juspodivm, 2019, p. 404.

${ }^{6}$ SARMENTO, Daniel. O mínimo existencial. Revista de Direito da Cidade, Rio de Janeiro, v. 8, n. 4, 2016, p. 1.647.
} 
Além de viabilizar de modo amplo a tutela jurisdicional dos cidadãos desprovidos de higidez financeira para suportar a morosidade do procedimento comum, ${ }^{7}$ os Juizados Especiais também visam à promoção da eficiência do aparato jurisdicional como um todo, pois, quando o conflito detém baixa complexidade e menor repercussão econômica, a baliza da proporcionalidade sinaliza a desnecessidade da adoção de um procedimento com custos e tramitação idênticos àqueles despendidos no rito comum. ${ }^{8}$

Com a Lei 10.259/01, essa baliza também foi transladada para o âmbito federal e, consequentemente, para os litígios envolvendo a seara previdenciária. A partir do referido diploma legal, os litígios afeitos à competência da Justiça Federal também seriam submetidos a um rito simplificado caso o valor da causa não ultrapassasse o limiar de 60 (sessenta) salários-mínimos.

Segundo bem aponta José Antonio Savaris, o intuito principal dessa medida foi o de incorporar a experiência de acessibilidade, celeridade e informalidade dos Juizados Especiais Estaduais às ações movidas na esfera da Justiça Federal, uma vez que essa instância jurisdicional também comportava litígios que, embora de menor expressão econômica, também estampavam uma inarredável importância existencial - exemplos claros são as demandas que envolvem a concessão de medicamentos ou de benefícios previdenciários. ${ }^{9}$

Ocorre que a lide previdenciária, em seu estado natural, é marcada por uma latente assimetria entre os polos processuais. De um lado, o INSS detém ampla capacidade financeira e institucional para defender os seus interesses em juízo, ao passo que, de outro, o requerente do benefício previdenciário encontra-se numa presumível situação de vulnerabilidade social, econômica e informacional, sobretudo ao levar-se em consideração que todas as prestações do seguro social revolvem alguma situação de risco à integridade

\footnotetext{
${ }^{7}$ ARENHART, Sérgio Cruz; MARINONI, Luiz Guilherme; MITIDIERO, Daniel. Novo curso de processo civil: tutela dos direitos mediante procedimentos diferenciados. Op. cit., p. 45-47.

${ }^{8}$ Neste particular, remete-se às lições de Remo Capino, no sentido de que o princípio da proporcionalidade perfaz uma ferramenta assaz útil para o equilíbrio panprocessual do funcionamento dos serviços prestados pela jurisdição. $\mathrm{O}$ autor, ao abordar a necessidade de adequação dos contornos do procedimento à complexidade da causa submetida ao crivo da jurisdição, afirma que causas que envolvem suportes fático-jurídicos simples devem ser guiadas por um procedimento célere e ágil, ao passo que causam que lidam com controvérsias complexas devem ser norteadas por um procedimento mais extenso e aprofundado, cujos contornos permitam a discussão de todas os pontos pertinentes ao litígio. Nesse sentido: CAPONI, Remo. O princípio da proporcionalidade na justiça civil: primeiras notas sistemáticas. Traduzido por Sérgio Cruz Arenhart. Revista de Processo, São Paulo, v. 192, fev., 2011, p. 411-412.

${ }^{9}$ SAVARIS, José Antonio. Direito processual previdenciário. 7. ed. Curitiba: Alteridade, 2018, p. 539-540.
} 
física e moral do cidadão - a exemplo da doença, da invalidez, da idade avançada e da morte de um membro mantenedor do núcleo familiar. ${ }^{10}$

Nesse campo, a premente necessidade de criação de uma justiça especializada já se encontrava discriminada nos clássicos escritos de Cappeletti e Garth, os quais pontuavam que "os obstáculos criados por nossos sistemas jurídicos são mais pronunciados para as pequenas causas e para os autores individuais, especialmente os mais pobres", razão pela qual "é de se esperar que os indivíduos tenham mais dificuldades para afirmar seus direitos quando a reivindicação deles envolva ações judiciais por danos relativamente pequenos, contra grandes organizações". ${ }^{11}$

Este é exatamente o cenário comumente visualizado no processo judicial previdenciário: primeiro, porque envolve um conflito no qual indivíduos em situação de risco social litigam contra uma grande organização governamental (INSS), a Fazenda Pública num sentido amplo; segundo, porque a maioria das causas previdenciárias engloba valores diminutos se comparados aos montantes pecuniários usualmente vislumbrados nas demandas cíveis em sentido estrito - vale relembrar, apenas, que o valor diminuto da causa não exclui a complexidade, muito menos a importância social, das ações dessa natureza. ${ }^{12}$

Por isso, a instauração dos Juizados Especiais Federais representou significativo avanço na promoção do direito fundamental à previdência social, eis que as peculiaridades do rito exposto na Lei 10.259/01 romperam inúmeros óbices materiais e formais que impediam a vindicação judicial de aposentadorias, benefícios por incapacidade e pensões. ${ }^{13}$

Nada obstante, se por um lado teóricos como Lenio Streck e Gilmar Ferreira Mendes acentuam que a legislação responsável pela criação dos Juizados Especiais Federais propiciou um "resultado social louvável" porque possibilitou que parcela significativa da

\footnotetext{
${ }^{10}$ Ibidem, p. 59-63.

${ }^{11}$ CAPPELETTI, Mauro; GARTH, Bryant. Acesso à justiça. Traduzido por Ellen Gracie Northfleet. Porto Alegre: Sergio Antonio Fabris Editor, 1988, p. 28.

${ }^{12}$ SERAU JUNIOR, Marco Aurélio. Resolução do conflito previdenciário e direitos fundamentais. São Paulo: LTr, 2015, p. 121-122.

13 “(...) a maior vantagem apontada acerca dos Juizados Especiais Federais gravitou em torno da ideia de celeridade no procedimento. Ademais, outras conquistas importantes oriundas dessa lei residiam nas transformação no sentido de: agilizar a prestação jurisdicional; redução de prazos; eliminar o duplo grau obrigatório; cumprimento de sentença independentemente de precatório; determinação de prazos simples para Fazenda Pública; agravo apenas retido; recursos da sentença com efeito só devolutivo; eliminação de processo autônomo para a execução; e, finalmente, simplificação das providências para intimação e citação" (SERAU JUNIOR, Marco Aurélio. Curso de processo judicial previdenciário. 4. ed. São Paulo: Método, 2014, p. 400).
} 
população tivesse acesso à resolução de suas demandas em prazo adequado; ${ }^{14}$ por outro, é preciso reconhecer que a sistemática adotada por tal instância jurisdicional sofre contundentes críticas.

Nesse ponto, são corriqueiras as ponderações de que os protocolos usualmente adotados pelos servidores e magistrados dos Juizados Especiais Federais focam-se excessivamente na agilização da prestação jurisdicional, olvidando as garantias mais caras à cláusula do devido processo legal, como o direito fundamental à prova, o contraditório e a ampla defesa - sempre em prejuízo do requerente de benefícios previdenciários, polo processual mais vulnerável da demanda.

Lançando mão das enfáticas ponderações de Paulo Afonso Brum Vaz, os anseios desmedidos pela eficiência dos Juizados Especiais Federais redundaram numa espécie de "vale-tudo", em que os adágios da celeridade, informalidade e eficiência processual passaram a ser utilizados como "salvo conduto" para a mitigação das garantias fundamentais que regem o direito processual. Na ótica do autor, transformou-se os Juizados Especiais Federais em uma "justiça de segunda categoria". ${ }^{15}$

A partir desta perspectiva de entendimento sobre o acesso à justiça e o papel dos Juizados Especiais Federais que discutiremos, posteriormente, as implicações da Lei 13.994/2020 no âmbito desta esfera jurisdicional.

Para que cheguemos a contento nesse desiderato, deixaremos para o próximo tópico a análise das inovações procedimentais carreadas pelo diploma legal mencionado.

\section{INOVAÇÕES PROCESSUAIS TRAZIDAS PELA LEI 13.994/2020: AS AUDIÊNCIAS NÃO PRESENCIAIS (VIRTUAIS) DE CONCILIAÇÃO}

A Lei 13.994, publicada em 24.04.2020, possibilitou a realização de audiências de conciliação não presencial no âmbito dos Juizados Especiais Cíveis.

\footnotetext{
${ }^{14}$ STRECK, Lênio Luiz; MENDES, Gilmar Ferreira. Comentários ao art. 98 da CF. In: CANOTILHO, J.J. Gomes; SARLET, Ingo Wolfgang; MENDES, Gilmar Ferreira; STRECK, Lênio Luiz (coords.). Comentários à Constituição do Brasil. 2. ed. São Paulo: Saraiva Educação, 2018, p. 1.439.

${ }^{15}$ VAZ, Paulo Afonso Brum. Juizado Especial Federal e Direito Previdenciário: desafios para a realização da justiça social. In: SERAU JUNIOR, Marco Aurélio. FOLMANN, Melissa (orgs.). Previdência social: em busca da justiça social. São Paulo: LTr, 2015, p. 191-192.
} 
Este diploma legal deve ser compreendido como uma norma publicada no contexto de adequação do ordenamento jurídico brasileiro ao cenário de isolamento social decorrente da necessidade de contenção do novo coronavírus (COVID-19).

Fóruns fechados e prazos em curso, direitos em discussão ou sob risco de perecimento. Buscaram-se medidas de compatibilização dessas necessidades com aquela mencionada no parágrafo anterior, de confinamento social.

Foi acionada a prática de atos processuais mediante a utilização de recursos tecnológicos, possibilidade já admitida amplamente pelo Processo Civil, e sua utilização foi amplificada no âmbito dos Juizados Especiais Cíveis e, por obra do art. $1^{\circ}$, da Lei 10.259/2001, também nos Juizados Especiais Federais.

É importante pontuar que o CPC/2015, diploma legal aplicável supletivamente a todas as modalidades de processos judiciais não penais, já previa a possibilidade de realização de atos processuais através de meios eletrônicos. Nesse sentido, adscreve o art. 193 do diploma processual que "os atos processuais podem ser total ou parcialmente digitais, de forma a permitir que sejam produzidos, comunicados, armazenados e validados por meio eletrônico, na forma da lei”.

No âmbito dos Juizados Especiais, o entrelaçamento entre as inovações tecnológicas e a praxe processual é ainda mais latente. Como bem relatam Humberto Dalla Bernadina de Pinho e Márcia Michele Garcia Duarte, os Juizados Especiais figuraram como uma espécie de lócus da experimentação do processo eletrônico no direito brasileiro, já que foram uma das instâncias pioneiras no que diz respeito à informatização de peças processuais. ${ }^{16}$

A inovação trazida pela Lei $13.994 / 2020$, portanto, não é medida processual deslocada do que o ordenamento jurídico-processual já vinha disciplinando e permitindo. Traduz-se, assim, na ideia de não somente produzir "um mero investimento tecnológico externo ao processo, mas sim da utilização tecnológica determinante de novos conceitos procedimentais". ${ }^{17}$

\footnotetext{
${ }^{16}$ Nesse sentido, os autores descrevem que o projeto-piloto adotado na comarca de São Sebastião do Caí, nos Juizados Especiais Estaduais do Rio Grande do Sul, tratou-se de uma das primeiras experiências de utilização de processo eletrônico no Brasil. Para maiores informações: PINHO, Humberto Dalla Bernardina de; DUARTE, Márcia Michele Garcia. Os juizados especiais cíveis e o e-process: o exame das garantias processuais na esfera virtual. Revista Eletrônica de Direito Processual - REDP, Rio de Janeiro, v. 3, n. 3, 2009 , p. 56.

${ }^{17}$ BENUCCI, Renato Luís. A tecnologia aplicada ao Processo Judicial. Campinas: Millenium, 2007, p. 59.
} 
No caso em tela, permitindo a realização de audiências conciliatórias através de mecanismos de TIC, em um momento em que tem prevalecido o isolamento social e o fechamento dos fóruns.

Nesse escopo, sopesando a necessidade de dar continuidade aos serviços judiciais (suspensos durante o interregno de 19.03.2020 a 31.05.2020, em virtude das Resoluções $\mathrm{n}^{\circ}$ 313, 314 e 318 do CNJ) com a manutenção do distanciamento social, o legislador introduziu um $\S 2^{\circ}$ ao artigo 22 da Lei 9.099/95, que passou a prever, expressamente, a possibilidade de realização de conciliação não presencial no âmbito dos Juizados Especiais, propiciada pelo atual estágio da TIC - Tecnologia da Informação e Comunicação.

De acordo com o referido dispositivo, "é cabível a conciliação não presencial conduzida pelo Juizado mediante o emprego de recursos tecnológicos disponíveis de transmissão de sons e imagens em tempo real". Ainda de acordo com a nova redação do art. 22 , $2^{\circ}$, da Lei 9.099/95, a conciliação não presencial, realizada a partir da utilização de recursos de TIC, será posteriormente reduzida a termo escrito e instruída com os anexos pertinentes, os quais correspondem aos arquivos contendo as mídias de som e imagem, para posterior e eventual controle de fundamentação e legalidade dos atos praticados (nos termos do art. 93, IX, da Constituição Federal). ${ }^{18}$

Embora a Lei 13.994/2020 não exija expressamente, cremos que os Tribunais Regionais Federais, suas Corregedorias, bem como as Coordenadorias dos Juizados Especiais Federais, expedirão regulamentação desse dispositivo processual.

A regulamentação se prestaria especialmente a estabelecer padrões técnicas para esse procedimento (sistemas processuais - E-Proc, PJE, ESAJ - e ferramentas tecnológicas admitidas para a comunicação virtual - Telegram, Whatsapp, Zoom, Meets etc., bem como quais formatos de arquivos que poderão ser adotados - JPEG, MP4 etc.).

Além disso, a Lei 13.994/20 conferiu nova redação ao art. 23 da Lei 9.099/95, adicionando a possibilidade de prolação imediata da sentença pelo juiz togado (juiz de carreira) nas situações em que o demandado se recusa a participar da tentativa de conciliação não presencial. Nessa linha, o legislador entoou que, "se o demandado não comparecer ou

\footnotetext{
${ }^{18}$ Para uma interessante abordagem do tema do controle da fundamentação das decisões judiciais: KREPSKY, Giselle Marie; DIAS, Feliciano Alcides; SÁ, Priscila Zeni de. Decisão judicial e argumentação: limites da fundamentação sob uma observação sistêmica. Revista Eletrônica de Direito Processual - REDP, Rio de Janeiro, v. 22, n. 2, mai./ago., 2021.
} 
recusar-se a participar da tentativa de conciliação não presencial, o Juiz togado proferirá sentença".

Neste ponto, é importante salientar a preocupação com uma verdadeira cultura de redução de acervo de processos, pautada em entendimentos destoantes do prisma de acesso à ordem jurídica justa, a qual busca encontrar respaldo em dispositivos tais quais o art. 51, inciso I, da Lei 9.099/95.

As inovações da Lei 13.994/2020 devem ser consideradas em conjunto com algumas garantias voltadas à prática dos atos processuais por meio eletrônico contidas no CPC, em particular no artigo 194, cujo teor preconiza que a transladação dos litígios para o meio virtual pressupõe a obediência aos postulados da publicidade, acesso e participação das partes e de seus procuradores nas audiências e sessões de julgamento, disponibilidade, independência da plataforma computacional, acessibilidade e interoperabilidade dos sistemas, serviços dados e informações que o Poder Judiciário administre no exercício de suas funções. ${ }^{19}$

Também devem ser respeitadas garantias contidas na Lei 11.419/2006, a exemplo da disposição do art. $10, \S 2^{\circ}$, no sentido de que a indisponibilidade do sistema informatizado por motivo técnico prorroga automaticamente o prazo para o primeiro dia útil subsequente à resolução do problema: em situações como essa, a audiência não presencial de conciliação deverá, por analogia, ser remarcada para data oportuna, em que o sistema informatizado esteja em pleno funcionamento.

São importantes também as garantias previstas nos artigos 198 e 199, do CPC. Nesse sentido, compete ao Poder Judiciário manter gratuitamente, à disposição dos interessados, os equipamentos eletrônicos necessários para a consulta e a realização de atos processuais, bem como assegurar o acesso à rede mundial de computadores e aos aparatos virtuais necessários para a consulta de processos eletrônicos às pessoas com deficiência.

\footnotetext{
${ }^{19}$ Discorrendo sobre a noção de "disponibilidade", situada no art. 194 do CPC, Daniel Amorim Assumpção Neves leciona: "Disponibilidade é a qualidade de sistemas informáticos que permaneçam constantemente em funcionamento, salvo por curtos períodos de tempo em que fiquem fora do ar. Sistema indisponível - fora do ar - impede a prática de atos processuais por todos os sujeitos processuais, o Estado-juiz inclusive, mas a situação é certamente mais dramática para as partes, considerando que para elas o prazo é, ao menos em regra, próprio, e a preclusão temporal sempre estará a espreita para colocar a parte que deixa de praticar o ato no prazo legal em situação de desvantagem” (NEVES, Daniel Amorim Assumpção. Manual de Direito Processual Civil - volume único. 8. ed. Salvador: Juspodivm, 2016, p. 342).
} 
Como se pontuou logo no começo deste artigo, é evidente que o conjunto de inovações trazido pela Lei 13.994/20200 também é aplicável às lides previdenciárias que tramitam nos Juizados Especiais Federais, em razão da expressa autorização do art. $1^{\circ}$ da Lei $10.259 / 2001$.

Urge questionar, porém, a pertinência da aplicação da conciliação eletrônica no processo judicial previdenciário, tendo em vista as múltiplas peculiaridades presentes na relação processual firmada entre o segurado e o INSS.

\section{ENTRE AVANÇOS E RISCOS: UM EXAME CRÍTICO DA LEI 13.994/2020}

O exame crítico dos desdobramentos da Lei 13.994/2020 no âmbito das ações previdenciárias e dos Juizados Especiais Federais não corresponde, de modo algum, àquilo que a doutrina processualista aponta como uma perspectiva de rejeição às inovações tecnológicas ${ }^{20}$ - inclusive porque a celeridade e a eficiência propiciadas pela inserção da tecnologia nos processos judiciais é medida que promove o efetivo exercício dos direitos fundamentais. ${ }^{21}$ Trata-se, tão somente, de um cuidado para com as particularidades e, especialmente, das assimetrias e vulnerabilidades processuais que caracterizam esse tipo de demanda e esse cenário jurisdicional.

Em primeiro lugar, é relevante pontuar que o conteúdo da Lei 13.994/2020 encontra harmonia com a sistemática legal dos Juizados Especiais. Isso porque, desde o art. 98, inciso I, da Constituição Federal, é possível observar que a consensualidade se trata do princípio fundamental que estrutura os Juizados Especiais. ${ }^{22}$

De fato, muito antes da promulgação do CPC de 2015 - responsável por conferir amplo estímulo à autocomposição em todas as modalidades de processos não penais,$- \mathrm{o}$ art. $2^{\text {o }}$ da Lei 9.099/95 já impunha às partes e ao juízo o dever de buscar, sempre que possível, a conciliação ou a transação. Portanto, a ótica dos juizados especiais “inverte, propositalmente,

\footnotetext{
${ }^{20}$ BENUCCI, Renato Luís. A tecnologia aplicada ao Processo Judicial. Op. cit., p. 62.

${ }^{21}$ Sobre o ponto, vale conferir: ALMEIDA FILHO, José Carlos de Araújo. Humano, demasiadamente eletrônico. Eletrônico, demasiadamente humano: a informatização judicial e o fator humano. Revista Eletrônica de Direito Processual - REDP, Rio de Janeiro, v. 5, n. 5, 2010, p. 413-414.

${ }^{22}$ VAZ, Paulo Afonso Brum. Princípio da consensualidade: nuances de sua prática nos Juizados Especiais Federais. In: SAVARIS, José Antonio; STAFFEN, Márcio Ricardo; BODNAR, Zenildo (orgs.). Juizados especiais federais: contributos para uma releitura. Itajaí: UNIVALI, v. 1, 2014, p. 119.
} 
a ordem das funções: a conciliatória precede a decisória e a executória, desvelando o caráter supletivo da fase decisória". ${ }^{23}$

Mais do que isso, ao conferir primazia à conciliação e à mediação, pretende-se consolidar o princípio da razoável duração do processo tanto no plano endoprocessual quanto no plano macroprocessual, na medida em que o aumento do índice de autocomposição nos juizados é duplamente benéfico: possibilita à parte necessitada a rápida concessão do direito vindicado e, concomitantemente, diminui o congestionamento gerado no Poder Judiciário com a contínua multiplicação de demandas que tramitam desde a fase postulatória até a recursal, processamento que consome o exíguo tempo de trabalho das varas e das turmas recursais que compõem os Juizados Especiais. ${ }^{24}$

Voltando os olhares ao processo judicial previdenciário, vê-se que a demanda por celeridade é ainda mais acentuada. É que os benefícios previdenciários perfazem verbas substitutivas aos rendimentos ordinários do trabalhador, razão pela qual são essenciais para a manutenção das necessidades básicas vinculadas ao mínimo vital e à dignidade humana. ${ }^{25}$

Também, é comum que o processo previdenciário veicule no polo ativo indivíduos de idade avançada, combalidos por alguma doença, desprovidos de renda para sustento próprio ou vulnerados por alguma outra situação de risco social, de modo que a implementação tardia do benefício poderá impedir a fruição do direito material vindicado. ${ }^{26}$

Agravando esse quadro, é importante sublinhar que, embora nos Juizados Especiais Federais se processem e julguem causas de pequeno valor, estas, em geral, estão longe se constituírem em causas de menor complexidade. ${ }^{27}$

\footnotetext{
${ }^{23}$ Ibidem, p. 119.

${ }^{24}$ Para maiores informações sobre os motivos que ensejam o estímulo à autocomposição no âmbito do Poder Judiciário: MANCUSO, Rodolfo de Camargo. Acesso à justiça: condicionantes legítimas e ilegítimas. Op. cit., p. 365-370.

25 "Portanto, a natureza da relação jurídica discutida nesse específico tipo de demanda (concernente à sobrevivência/subsistência humana), bem como, em muitos casos, a consideração sobre os legitimados a figurar no polo passivo (pessoas com elevada idade), revelam a necessidade de assegurar-se, ao Processo Judicial Previdenciário, a sua específica celeridade, independentemente da garantia geral de celeridade concedida a todos os processos judiciais e administrativos" (SERAU JUNIOR, Marco Aurélio. Curso de processo judicial previdenciário. Op. cit., p. 59).

${ }^{26}$ Neste mesmo sentido:SAVARIS, José Antonio. Direito processual previdenciário. Op. cit., p. 115.

${ }^{27}$ FERREIRA, William Santos. Prova pericial nos Juizados Especiais Federais: acesso à justiça e modelos de operacionalização do direito constitucional à prova. In: SERAU JUNIOR, Marco Aurélio; DONOSO, Denis (coords.). Juizados Especiais Federais - reflexões após 10 anos de sua instalação. 2. ed. Curitiba: Juruá, 2014, p. 305-306.
} 
Justamente pela celeridade ínsita aos métodos autocompositivos de resolução de litígios, a adoção da conciliação e da mediação não só é possível, como também é desejável no âmbito dos processos judiciais previdenciários. De fato, os métodos autocompositivos possibilitam que a mora judicial, tão deletéria para aqueles que suportam os riscos que desencadeiam a atuação da Seguridade Social, seja suprida mediante a celebração de um acordo que outorgue, de imediato, os rendimentos aos quais o segurado da Previdência Social faz jus. ${ }^{28}$

Assim, é certo que o comando exarado pela Lei 13.994/2020 não encontra nenhum óbice formal na legislação vigente; ao contrário, na realidade, a inserção das novas tecnologias no diálogo processual visa aumentar as possibilidades disponíveis para prática da conciliação, o que se coaduna com a válvula motriz do microssistema dos Juizados Especiais.

Nada obstante, embora promissora a proposta oferecida pela Lei 13.994/2020, existem algumas ressalvas que não podem ser desprezadas.

A primeira delas reside na problemática questão do acesso à informação.

Como já mencionado, é consabido que os indivíduos que usualmente compõem o polo ativo da demanda previdenciária encontram-se num contexto de hipossuficiência informacional. Seja em razão da idade avançada, da indisponibilidade de renda econômica para a aquisição de instrumentos telemáticos (smarthphones e computadores) ou dos cediços óbices à promoção do acesso democratizado à informação, é certo que inúmeros litigantes irão se deparar com situações nas quais o comparecimento à audiência de conciliação não presencial mostrar-se-á excessivamente difícil ou até mesmo inviável.

Neste particular, o direito processual é instado a lidar com o intrincado fenômeno que Fernanda Tartuce denomina de "vulnerabilidade cibernética", que engloba a sonegação do acesso à justiça dos indivíduos que não detém capacidade econômica para adquirir equipamentos hábeis para acompanhar as diligências relacionadas às suas demandas, bem como dos indivíduos que revelam dificuldade de manipulá-los com proficuidade. ${ }^{29}$

\footnotetext{
${ }^{28}$ SERAU JUNIOR, Marco Aurélio. Resolução do conflito previdenciário e direitos fundamentais. Op. cit., p. 124-125.

${ }^{29}$ SILVA, Fernanda Tartuce. Vulnerabilidade como critério legítimo de desequiparação no processo civil. 384 f. Tese (Doutorado em Direito Processual). Universidade de São Paulo, São Paulo, 2011, p. 203-205.
} 
Além disso, a doutrina de Renato Luís Benucci aponta que, apesar de o preço dos aparatos tecnológicos terem se tornado mais acessíveis, os chamados "desconectados" ainda refletem uma parcela significativa da população brasileira, eis que "a implantação da tecnologia informática tem se caracterizado pela grande concentração em determinados segmentos sociais e em determinadas áreas geográficas", ${ }^{30}$ o que redunda num distanciamento dos cidadãos em relação à concretização de seus direitos pela via jurisdicional.

Diante disso, imperioso consignar que a aplicação do $\S 2^{\circ}$ do art. 22 da Lei 13.994/2020 deverá ser cuidadosamente balizada pelo postulado da razoabilidade. ${ }^{31}$

Atentando-se aos contornos do caso concreto, o julgador deverá avaliar se o autor da demanda previdenciária detém acesso às garantias de inclusão digital, pois a designação da audiência de conciliação não presencial somente poderá ocorrer nos casos em que a realização do ato processual pela via eletrônica não acarretar qualquer tipo de prejuízo ao segurado.

Apesar do intuito expresso da norma de facilitar a autocomposição nos Juizados Especiais, é indubitável que a previsão de audiência telemática não pode esbarrar nas garantias inerentes à cláusula do devido processo legal. Como bem pontua a doutrina, "a prática eletrônica de atos processuais não pode importar em violação dos direitos fundamentais que compõem o direito ao processo justo", motivo pelo qual "os sistemas de automação processual devem respeitar a publicidade dos atos, o acesso e a participação das partes e de seus procuradores". 32

Assim, caso o autor da demanda previdenciária não possua acesso aos mecanismos de inclusão digital, duas alternativas mostram-se viáveis: (i) poderá o juiz designar a audiência de conciliação não presencial e, concomitantemente, apresentar ao demandante a possibilidade de participar do ato processual através de equipamentos eletrônicos mantidos

\footnotetext{
${ }^{30}$ BENUCCI, Renato Luís. A tecnologia aplicada ao Processo Judicial. Op. cit., p. 177-178.

${ }^{31}$ Entenda-se, aqui, o postulado da razoabilidade no sentido dado por Humberto Ávila, o qual expõe que "a razoabilidade é utilizada como diretriz que exige a relação das normas gerais com as individualidades do caso concreto, quer mostrando sob qual perspectiva a norma deve ser aplicada, quer indicando em quais hipóteses o caso individual, em virtude de suas especificidades, deixa de se enquadrar na norma geral"(ÁVILA, Humberto. Teoria dos princípios: da definição à aplicação dos princípios jurídicos. 18. ed. São Paulo: Malheiros, 2018, p. 194-195).

${ }^{32}$ ARENHART, Sérgio Cruz; MARINONI, Luiz Guilherme; MITIDIERO, Daniel. Código de Processo Civil comentado. 3. ed. São Paulo: Thomson Reuters Brasil, 2018, p. 341.
} 
pelo próprio Poder Judiciário, circunstância que encontra expressa guarida no art. 198 do CPC; (ii) manter a designação de audiências presenciais, já que o art. 22, § 2º da Lei 9.099/95 elenca a audiência de conciliação não presencial como diligência opcional, sendo lícito o seu afastamento nos casos em que o uma das partes não possui o maquinário necessário para acompanhar o ato processual eletrônico.

Outras soluções processuais também poderão ser cogitadas a partir da colocação em prática destes novos procedimentos criados pela Lei 13.994/2020. Desde já, é certeiro afirmar que deve ser evitada a perspectiva que dê preferência à extinção do processo com respaldo em dispositivos legais como art. 51, inciso I, da Lei 9.099/95, e outros similares.

O CPC/2015 inaugurou a fase da primazia do julgamento do mérito e, embora a Lei 13.994/2020 disponha sobre um procedimento específico, não se pode perder de vista aquele princípio processual geral.

Ocorre que a Constituição Federal e o CPC de 2015 constituem, conjuntamente, o plexo normativo definidor do núcleo duro do devido processo legal (processo justo), razão pela qual as normas fundamentais do processo civil (arts. $1^{\circ}$ a 12 do CPC) não podem ter sua aplicação afastada nos Juizados Especiais Federais. ${ }^{33}$ Desse modo, os princípios da paridade de armas e isonomia processual, delineados no art. $7^{\circ}$ do CPC, também impõem aos órgãos julgadores dos Juizados Especiais o dever de adequar as regras procedimentais ordinárias às peculiaridades geradas pela assimetria econômica e material vislumbrada entre os polos do litígio.

Nesse mote, conforme aponta a doutrina, "tem o juiz, na condução do processo, o dever de interpretar a legislação processual civil em conformidade com os direitos fundamentais processuais", de modo a preferir "para a solução dos casos o sentido legal que concretize de maneira ótima os direitos fundamentais". 34

No novel contexto proporcionado pela Lei 13.994/2020, a hermenêutica que menos infringe direitos fundamentais dos segurados que litigam nos Juizados Especiais Federais é aquela que afasta a aplicação imediata do art. 51, inciso I, da Lei 9.099/95 quando a parte autora deixa de comparecer à audiência de conciliação não presencial. É que os princípios

\footnotetext{
${ }^{33}$ Defendendo que as normas principiológicas nas passagens iniciais do CPC se aplicam, em sua maioria, à dinâmica dos Juizados Especiais Federais: ATAÍDE JUNIOR, Vicente de Paula. O CPC/2015 e os Juizados Especiais Cíveis. Revista Brasileira de Direito Previdenciário, v. 7, n. 38, abr./mai., 2017.

${ }^{34}$ ARENHART, Sérgio Cruz; MARINONI, Luiz Guilherme; MITIDIERO, Daniel. Código de Processo Civil comentado. Op. cit., p. 301.
} 
da paridade de armas e isonomia processual somente estarão assegurados se o juiz se atentar para a costumeira hipossuficiência informacional, material e econômica do segurado, conferindo-lhe a oportunidade de se apresentar em nova audiência caso as dificuldades de acesso à tecnologia causem óbice ao comparecimento no ato processual telemático.

De fato, o litigante hipossuficiente não pode ser penalizado com a extinção do processo sem a resolução do mérito em decorrência da sua própria exclusão digital. Tal solução contraria as normas fundamentais que regem todas as modalidades de processos cíveis, especialmente o art. $8^{\circ}$ do $\mathrm{CPC} / 2015$, o qual dispõe que, durante a interpretação e aplicação dos textos legais, "o juiz atenderá aos fins sociais e às exigências do bem comum, resguardando e promovendo a dignidade da pessoa humana e observando a proporcionalidade, a razoabilidade, a legalidade, a publicidade e a eficiência".

Portanto, deve ser mitigada a aplicação do art. 51, inciso I, da Lei 9.099/95 nos casos em que o requerente de benefícios previdenciários deixa de comparecer à audiência de conciliação não presencial em razão de óbices causados pelo seu contexto de exclusão digital.

Outrossim, pertinente o destaque de uma ressalva complementar. $\mathrm{O}$ art. $22, \S 2^{\circ}$, da Lei 9.099/95, além de compactuar com o movimento de inserção gradativa das inovações tecnológicos no processo civil, também veicula o claro intuito de impedir que a parte ré se esquive da audiência de conciliação e mediação. Vale dizer: a partir da designação da audiência conciliatória por diligência eletrônica, dificilmente o réu poderá fornecer alguma justificativa apta a amparar o não comparecimento ao ato processual.

No entanto, ainda é possível indagar eventual ineficácia dessa medida no campo previdenciário.

Ocorre que, ao longo dos anos, o INSS carreia uma reiterada opinião desfavorável à resolução de demandas previdenciárias pela via da conciliação, sob o fundamento de que os interesses veiculados pela autarquia seriam indisponíveis. ${ }^{35}$ A título ilustrativo, tome-se o posicionamento externado pela Procuradoria Federal do Estado do Paraná no Ofício $\mathrm{n}^{\mathrm{o}}$ 0025/2016, por meio do qual o órgão sugeriu à Corregedoria Regional da Justiça Federal da $4^{a}$ Região que os magistrados deixassem de designar audiência de conciliação e mediação

\footnotetext{
${ }^{35}$ Para uma interessante crítica à visão clássica de que os direitos indisponíveis seriam supostamente impassíveis de autocomposição: VENTURI, Elton. Transação de direitos indisponíveis? Revista de Processo, São Paulo, v. 251, jan., 2016.
} 
em processos previdenciários, para fins de evitar que a parte autora comparecesse em ato judicial que "certamente teria resultado infrutífero".

Conjugando a mitigação das possibilidades de o INSS esquivar-se da audiência de conciliação não presencial com a sua predisposição desfavorável à autocomposição, é possível cogitar que a autarquia adotará a sua costumeira posição combativa nos momentos em que supostamente deveria imperar a consensualidade.

Ao invés de mostrar-se aberto ao efetivo diálogo com o segurado no ato processual eletrônico, o INSS intentará, de todos os modos, formular acordos que menos onerem os seus interesses e menos favoreçam os segurados - vale relembrar que, no âmbito judicial, o INSS tem como padrão de conduta a intensa recorribilidade e a refutação aos métodos autocompositivos de resolução de litígios. ${ }^{36}$

Ao fim e ao cabo, na égide do art. 22, $\S 2^{\circ}$, da Lei 9.099/95, é possível que a autarquia previdenciária, ao invés de desviar-se das tentativas de conciliação, passe a propor acordos desfavoráveis ao direito do segurado, isto é, acordos que veiculem prestações previdenciárias inferiores àquelas que o demandante realmente faria jus.

Num contexto dessa natureza, os interesses do segurado serão gravemente prejudicados, pois não são raras as situações em que o demandante não possui capacidade financeira para suportar todo o trâmite processual e, por via de consequiência, é obrigado a aceitar a proposta de acordo do INSS, ainda que desfavorável aos reais direitos conquistados durante o histórico laborativo.

Como já mencionado, o segurado se trata de um indivíduo abarcado por uma situação de hipossuficiência informacional, no sentido de que "os indivíduos não se encontram em situação de tomar decisões de forma informada e responsável, tendo em conta as possíveis consequências". 37

Nesse sentido, ante a notória disparidade entre os polos processuais da lide previdenciária, é plausível que a autarquia proponha um acordo contrário aos escopos da justiça social preconizada pela Constituição Federal, tolhendo o direito do cidadão ao percebimento do melhor benefício previdenciário, assegurado no plano regulamentar pelo art. 687 da Instrução Normativa $\mathrm{n}^{0}$ 77/2015 do INSS.

\footnotetext{
${ }^{36}$ SERAU JUNIOR, Marco Aurélio. Resolução do conflito previdenciário e direitos fundamentais. Op. cit., p. 60-61.

${ }^{37}$ SAVARIS, José Antonio. Direito processual previdenciário. Op. cit., p. 60.
} 
O jurista Owen Fiss, em célebre ensaio crítico à expansão das Alternative Dispute Resolution (ADR's) no processo civil estadunidense, problematizou o estímulo ao acordo nas demandas em que há desigualdade material, econômica ou informacional entre os litigantes. De acordo com Fiss, existem três principais fatores que tendem a gerar injustiças na autocomposição, gerando o favorecimento escuso dos interesses do litigante com maior poderio financeiro e, ao mesmo tempo, a negação dos direitos aos quais o litigante hipossuficiente faz jus. O primeiro fator se trata da dificuldade que o litigante hipossuficiente possui de lograr as orientações técnicas necessárias para o conhecimento dos limites e das possibilidades do acordo celebrado, porquanto a assimetria informacional dificulta o seu poder de negociação frente ao contendor que domina todas as nuances fáticas e jurídicas da controvérsia suscitada. O segundo fator, por sua vez, diz respeito à necessidade de recebimento imediato da prestação pelo litigante hipossuficiente, pois tal circunstância, não raro, compele-o a aceitar um acordo nitidamente prejudicial aos seus interesses para apressar o acautelamento de atribulações financeiras e existenciais. O terceiro, por fim, concerne à carência de renda do litigante hipossuficiente para custear os honorários advocatícios, custas processuais, instrução probatória e demais diligências adjacentes à demanda judicial, eis que tais intercorrências também o forçam a aderir a um acordo desfavorável para evitar o comprometimento de seu orçamento pessoal. ${ }^{38}$

O mesmo diagnóstico é traçado por Marc Galanter, ao sinalizar uma espécie de assimetria entre os "litigantes habituais" e os "litigantes eventuais". ${ }^{39}$ Ao vislumbrar-se os litígios previdenciários por essa ótica, vê-se que existe uma clara assimetria material e econômica entre o INSS e o pleiteante da aposentadoria ou do auxílio, pois, se o primeiro detém amplos recursos financeiros para suportar o "tempo do processo" sem prejuízos significativos, o segundo está perpassando por uma gradativa degradação de seu bem-estar, seja em razão do avanço da idade ou do agravamento de uma determinada moléstia.

Decerto, não é muito difícil imaginar um cenário no qual o segurado, a despeito de saber que faz jus a um benefício de extensão monetária muito mais ampla do que aquele sugerido na proposta de acordo do INSS, aceita a homologação da autocomposição porque

\footnotetext{
${ }^{38}$ FISS, Owen. Contra o acordo. Traduzido por Carlos Alberto Salles, Daniel Porto Godinho da Silva e Melina Medeiros de Rós. In: FISS, Owen. Um novo Processo Civil: estudos norte-americanos sobre Jurisdição, Constituição e sociedade. São Paulo: Revista dos Tribunais, 2004, p. 125

${ }^{39}$ GALANTER, Marc. Por que "quem tem" sai na frente: especulações sobre os limites da transformação no direito. Traduzido por Ana Carolina Chasin. São Paulo: FGV, 2018, p. 49-52.
} 
o sofrimento causado pela carência de renda necessária para a satisfação de suas necessidades básicas clama por uma cessação imediata. ${ }^{40}$

Evidentemente, não se olvidam as inúmeras vantagens correlatas à autocomposição na esfera previdenciária, no entanto é imprescindível que essas intercorrências subjacentes ao estímulo da conciliação não presencial nos Juizados Especiais Federais sejam também consideradas.

Tendo em vista que a consensualidade se trata de um princípio fundamental dos Juizados Especiais, não há dúvidas de que a Lei 13.994/2020 traz relevante avanço para o aperfeiçoamento dessa instância judicial. Nada obstante, é preciso sopesar cuidadosamente as repercussões desta medida nos direitos fundamentais do segurado, sejam eles de caráter processual (v.g. livre acesso aos atos processuais) ou material (v.g. direito à percepção do melhor benefício previdenciário).

\section{CONCLUSÕES}

Este artigo objetivou discutir o alcance da Lei 13.994/2020 no âmbito dos Juizados Especiais Federais, norma que foi editada no cenário de isolamento social que é característico do enfrentamento da disseminação do novo coronavírus (COVID-19), permitindo a realização de audiências de conciliação não presenciais (virtuais) no âmbito dos Juizados Especiais Cíveis - com alteração dos artigos 22 e 23 da Lei 9.099/95.

Como premissa para as discussões deste artigo, retomou-se a ideia motivadora da criação dos Juizados Especiais Federais, qual seja, a perspectiva de facilitação do acesso à justiça em relação às pequenas causas que tenham como mote a concessão ou revisão de benefícios previdenciários, analisando criticamente o atual estágio dessa modalidade de jurisdição. Nesse mote, conquanto os Juizados Especiais Federais tenham sido instaurados com o nobre intuito aperfeiçoar a dos direitos pela via jurisdicional, o anseio pela eficiência e celeridade resultou na mitigação das garantias que encandeiam o direito processual, como o direito fundamental à prova, o contraditório e à ampla defesa.

\footnotetext{
${ }^{40}$ Esse é justamente um dos argumentos utilizados por Owen Fiss para criticar o estímulo excessivo à prática dos acordos judiciais: FISS, Owen. Contra o acordo. Op. cit., p. 124-128.
} 
Na sequência, expôs-se as alterações procedimentais trazidas pela Lei 13.994/2020, em particular o modo pelo qual pode ocorrer a audiência não presencial de conciliação e seus principais efeitos jurídicos. Em virtude das medidas de isolamento social impostas pelo alastramento pandêmico do coronavírus (COVID-19), a Lei 13.994/2020 promoveu a expressa autorização da realização de audiências de conciliação virtuais no âmbito dos Juizados Especiais Cíveis e Federais, indicando que a ausência de comparecimento das partes pode redundar no sentenciamento imediato do feito.

Após, discutiu-se criticamente a aplicação dessa inovação ao cenário específico das ações previdenciárias, que é pautado por uma relevante assimetria processual entre as partes em litígio. Se, por um lado, a inovação da Lei 13.944/2020 é essencialmente positiva, por outro, deve ser considerada com certas ressalvas e cuidados quando aplicada nos Juizados Especiais Federais, diante das características inerentes a esse âmbito jurisdicional, sobretudo as vulnerabilidades processuais que configuram o polo ativo das ações previdenciárias.

Em razão disso, compete ao julgador aferir se o autor da demanda previdenciária possui acesso aos mecanismos tecnológicos necessários para o acompanhamento da audiência de conciliação virtual. Caso tal acesso esteja comprometido, deverá o juiz designar audiência de conciliação não presencial e informar o demandante sobre a possibilidade de este se valer dos equipamentos eletrônicos mantidos pelo próprio Poder Judiciário ou, alternativamente, manter a designação de audiência de conciliação presencial.

Além disso, em virtude das atribulações inerentes ao fenômeno da exclusão digital, recomendou-se que deve ser mitigada a aplicação do art. 51, inciso I, da Lei 9.099/95 nos casos em que o requerente de benefícios previdenciários deixa de comparecer à audiência de conciliação virtual.

Por fim, diagnosticou-se que as medidas implementadas pela Lei 13.944/2020 possivelmente acarretarão uma presença mais constante do INSS nas tentativas de conciliação empreendidas nos Juizados Especiais Federais, visto que, com o advento da modalidade virtual de audiências, dificilmente a autarquia terá justificativas para se eximir de comparecer no ato processual. Apesar dos evidentes ganhos com a promoção da consensualidade no âmbito dos Juizados Especiais Federais, as autocomposições realizadas nos litígios previdenciários devem ser avaliadas com parcimônia, eis que a assimetria econômica e informacional vislumbrada entre os litigantes, não raramente, forçam o litigante 
hipossuficiente a anuir com uma proposta de acordo que não reflete a real extensão de seu direito.

\section{REFERÊNCIAS:}

ALMEIDA FILHO, José Carlos de Araújo. Humano, demasiadamente eletrônico. Eletrônico, demasiadamente humano: a informatização judicial e o fator humano. Revista Eletrônica de Direito Processual - REDP, Rio de Janeiro, v. 5, n. 5, 2010.

ARENHART, Sérgio Cruz; MARINONI, Luiz Guilherme; MITIDIERO, Daniel. Novo curso de processo civil: tutela dos direitos mediante procedimentos diferenciados, vol. 3. 3. ed. São Paulo: Revista dos Tribunais, 2017.

ARENHART, Sérgio Cruz; MARINONI, Luiz Guilherme; MITIDIERO, Daniel. Código de Processo Civil comentado. 3. ed. São Paulo: Thomson Reuters Brasil, 2018.

ATAÍDE JUNIOR, Vicente de Paula. O CPC/2015 e os Juizados Especiais Cíveis. In: Revista Brasileira de Direito Previdenciário, v. 7, n. 38, abr./mai., 2017.

ÁVILA, Humberto. Teoria dos princípios: da definição à aplicação dos princípios jurídicos. 18. ed. São Paulo: Malheiros, 2018.

BARBOSA MOREIRA, José Carlos. A função social do processo civil moderno e o papel do juiz e das partes na direção e na instrução do processo. Revista de processo, São Paulo, v. 37, 1985.

BENUCCI, Renato Luís. A tecnologia aplicada ao Processo Judicial. Campinas: Millenium, 2007.

CAPPELLETTI, Mauro; GARTH, Bryant. Acesso à justiça. Traduzido por Ellen Gracie Northfleet. Porto Alegre: Sergio Antonio Fabris Editor, 1988.

CAPONI, Remo. O princípio da proporcionalidade na justiça civil: primeiras notas sistemáticas. Revista de processo, São Paulo v. 36, n. 192, fev. 2011.

DINAMARCO, Cândido Rangel. A instrumentalidade do processo. 14. ed. São Paulo: Malheiros, 2009.

FERREIRA, William Santos. Prova pericial nos Juizados Especiais Federais: acesso à justiça e modelos de operacionalização do direito constitucional à prova. In: SERAU 
JUNIOR, Marco Aurélio; DONOSO, Denis (coords.). Juizados Especiais Federais - reflexões após 10 anos de sua instalação, $2^{\text {a }}$ ed., Curitiba: Juruá, 2014.

FISS, Owen. Contra o acordo. Traduzido por Carlos Alberto Salles, Daniel Porto Godinho da Silva e Melina Medeiros de Rós In: FISS, Owen. Um novo Processo Civil: estudos norte-americanos sobre Jurisdição, Constituição e sociedade. São Paulo: Revista dos Tribunais, 2004.

GALANTER, Marc. Por que "quem tem" sai na frente: especulações sobre os limites da transformação no direito. Traduzido por Ana Carolina Chasin. São Paulo: FGV, 2018.

KREPSKY, Giselle Marie; DIAS, Feliciano Alcides; SÁ, Priscila Zeni de. Decisão judicial e argumentação: limites da fundamentação sob uma observação sistêmica. Revista Eletrônica de Direito Processual - REDP, Rio de Janeiro, v. 22, n. 2, mai./ago., 2021

MANCUSO, Rodolfo de Camargo. Acesso à justiça: condicionantes legítimas e ilegítimas. 3. ed. Salvador: Juspodivm, 2019.

NEVES, Daniel Amorim Assumpção. Manual de Direito Processual Civil - volume único. 8. ed. Salvador: Juspodivm, 2016.

PINHO, Humberto Dalla Bernardina de; DUARTE, Márcia Michele Garcia. Os juizados especiais cíveis e o e-process: o exame das garantias processuais na esfera virtual. Revista Eletrônica de Direito Processual - REDP, Rio de Janeiro, v. 3, n. 3, 2009.

SARMENTO, Daniel. O mínimo existencial. Revista de Direito da Cidade, Rio de Janeiro, v. 8, n. 4, 2016.

SAVARIS, José Antônio. Direito processual previdenciário. 7. ed. Curitiba: Alteridade, 2018.

SERAU JUNIOR, Marco Aurélio. Curso de processo judicial previdenciário. 4. ed. Rio de Janeiro: Forense, 2014.

SERAU JUNIOR, Marco Aurélio. Resolução do conflito previdenciário e direitos fundamentais. São Paulo: LTr, 2015.

SILVA, Fernanda Tartuce. Vulnerabilidade como critério legítimo de desequiparação no processo civil. 384 f. Tese (Doutorado em Direito Processual). Universidade de São Paulo, São Paulo, 2011. 
STRECK, Lenio Luiz; MENDES, Gilmar Ferreira. Comentários ao art. 98 da CF. In: CANOTILHO, J.J. Gomes; SARLET, Ingo Wolfgang; MENDES, Gilmar Ferreira; STRECK, Lênio Luiz (coords.) Comentários à Constituição do Brasil. 2. ed. São Paulo: Saraiva Educação, 2018.

TARTUCE, Fernanda; BRANDÃO, Débora. Mediação e conciliação online, vulnerabilidade cibernética e destaques do ato normativo $\mathrm{n}^{0} 1 / 2020$ do NUPEMEC/SP. Cadernos Jurídicos, São Paulo, ano 21, n. 55, jul./set., 2020.

VAZ, Paulo Afonso Brum. Juizado Especial Federal e Direito Previdenciário: desafios para a realização da justiça social. In: Previdência social: em busca da justiça social. SERAU JUNIOR, Marco Aurélio. FOLMANN, Melissa (orgs.). São Paulo: LTr, 2015.

VAZ, Paulo Afonso. Princípio da consensualidade: nuances de sua prática nos Juizados Especiais Federais. In: SAVARIS, José Antônio; STAFFEN, Márcio Ricardo; BODNAR, Zenildo (org.). Juizados especiais federais: contributos para uma releitura, Itajaí: UNIVALI, v. 1, 2014.

VENTURI, Elton. Transação de direitos indisponíveis? Revista de Processo, São Paulo, v. 251, jan., 2016. 